\title{
Evaluation of Emergency Cooling Water Suystem
}

by

Reactor Technology

E. I. du Pont de Nemours and Company

Savannah River Site

Aiken, South Carolina 29808

\section{MASTER}

\section{DOE Contract No.}

This paper was prepared in connection with work done under the above contract number with the U. S. Department of Energy. By acceptance of this paper, the publisher and/or recipient acknowledges the U. S. Government's right to retain a nonexclusive, royalty-free license in and to any copyright covering this paper, along with the right to reproduce and to authorize others to reproduce all or part of the copyrighted paper. 


\section{DISCLAIMER}

This report was prepared as an account of work sponsored by an agency of the United States Government. Neither the United States Government nor any agency thereof, nor any of their employees, makes any warranty, express or implied, or assumes any legal liability or responsibility for the accuracy, completeness, or usefulness of any information, apparatus, product, or process disclosed, or represents that its use would not infringe privately owned rights. Reference herein to any specific commercial product, process, or service by trade name, trademark, manufacturer, or otherwise does not necessarily constitute or imply its endorsement, recommendation, or favoring by the United States Government or any agency thereof. The views and opinions of authors expressed herein do not necessarily state or reflect those of the United States Government or any agency thereof.

This report has been reproduced directly from the best available copy.

Available to DOE and DOE contractors from the Office of Scientific and Technical Information, P. O. Box 62, Oak Ridge, TN 37831; prices available from (423) 576-8401.

Available to the public from the National Technical Information Service, U. S. Department of Commerce, 5285 Port Royal Road, Springfield, VA 22161. 


\section{DISCLAIMER}

Portions of this document may be illegible in electronic image products. Images are produced from the best available original document. 
Rough Draft

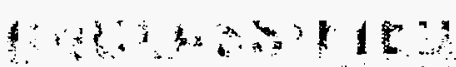

DPSP $-68-207-1$

October 1,1968

\section{EXALUATION OF EMERGENCY COOLTNG WATER SYSTEM}

\section{$\longrightarrow$}
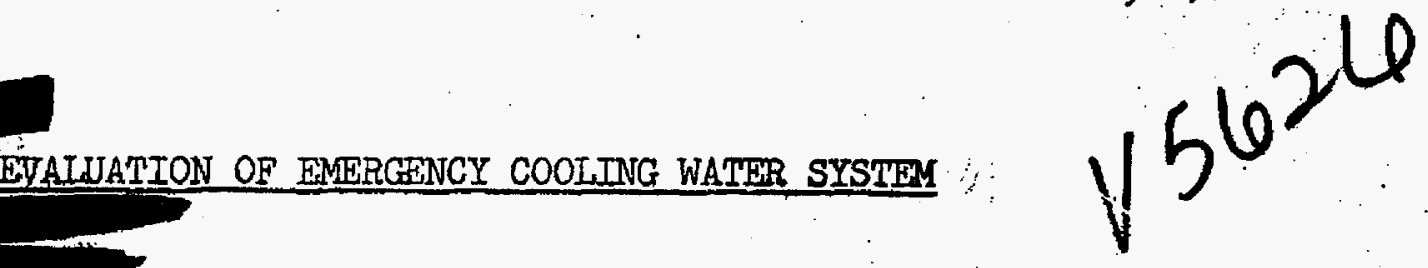

I. Percent of Emergency Cooling Water That Goes to Fuel

\section{Distribution}

\section{INFORMATION ONLY}

Wilmington

1. J. A. List

$\underline{\text { SRL }}$

3. S. Mirshak

4. G. F. Merz

$\underline{\text { SRP }}$

5. I. W. Fox

6. F. R: Field - E. O. Kiger

7. J. P. Maloney

8. J. H. Hinton

9. C. J. Temple

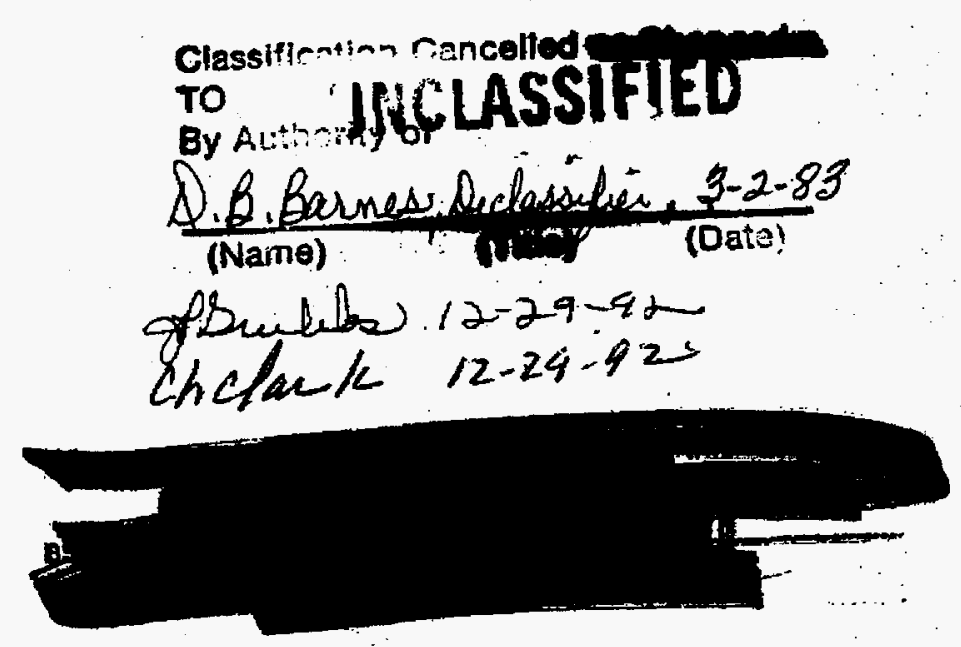

1):-3:- :

Exclunen Fa-i: aU:

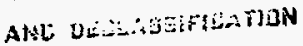


I. Percent of ECW That Goes To Fuel

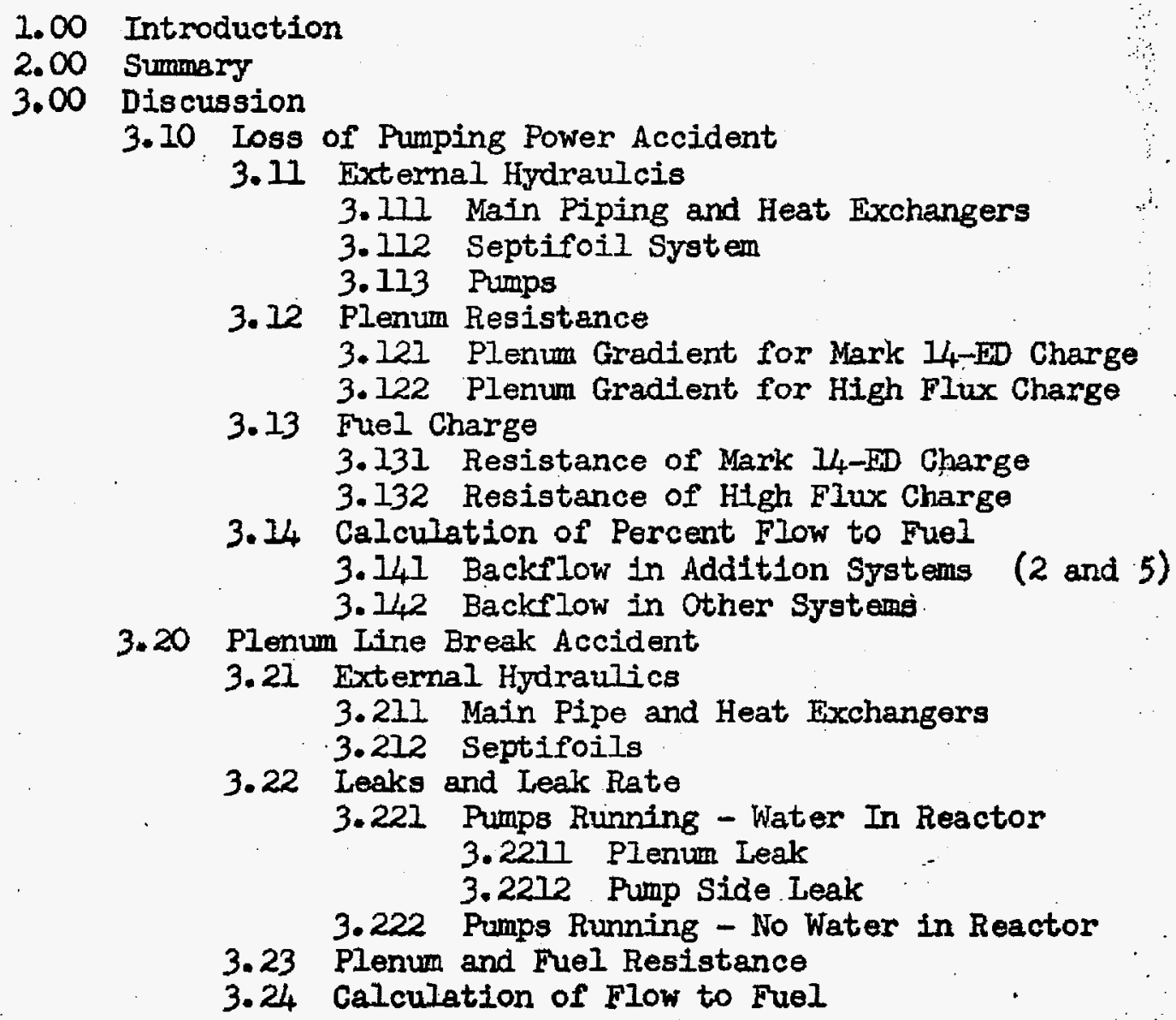

When separated from ponclosures, hapatle this document 
onering

\section{Percent of Emergency Cooling Water That Goes to Fuel}

\section{I.00 INTRODUCTION}

Evaluation of the adequacy of the emergency cooling water addition syrtem (ECWA syotem) requires analysis of the postulated accidents for which the system is required to function. Analysis of these accidents requires a knowledge of the amount of the ECW added that goes to the fuel; both the total amount to the fuel and the amount to the central fuel assemblies. This section of the memorandum presents the methods used to calculated the flows to the fuel and the results of the calculations.

\subsection{SUMMARY}

Table 2.1 shows the percent of the ECW that will go to the fuel for the loss of pumping power accident with the reactor full and for the doubleended plenum inlet line break accident (the "70 Criteria" design basis accident - DBA) with an ECW addition rate of 11,000 gpm. It also shows the expected flow rate to the central fuel tubes." These accidents are the most severe of the no leak and leak accidents so flows would be higher for all other accidents. These results were used in evaluating the adequacy
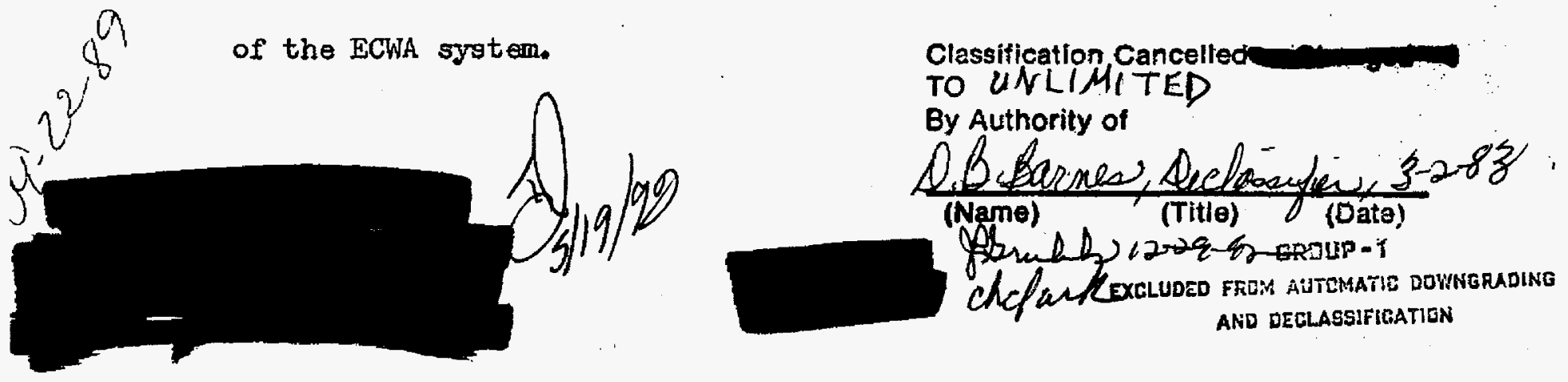
Rough Draft
$-2-$

Table 2.1

\section{FLOW TO FUEL}

Charge

Accident

Percent ECW to Fuel

- AlI Rotovalyes Open

- Rotovalves 2 and 5 closed

- All Rotovalves Closed

- Pumps On - Rotovalves Open
ED

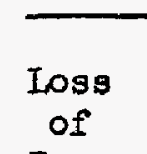

Pumps
RTR

October 1, 1968
Flow to Center Tube For Iarge

Leak With 11,000 GPM Supply to Plenum With A Leak In System $1,3,4$ or 6

\section{High Flux}

Loss 92,500

\begin{tabular}{lll} 
gpm & of \\
Leak & $\begin{array}{c}\text { gpm } \\
\text { Pumps }\end{array}$ \\
\hline
\end{tabular}

$\begin{array}{rrrr}79 & - & 44 & - \\ 87 & - & 57 & - \\ 100 & - & 100 & - \\ -\cdots & 76.4 & - & 60.9\end{array}$


RTR

October 1, 2968

3.00 DISCUSSION

The calculation methods are separated into two sections because the flow paths and hydraulic conditions are different for the two accidenta. For loss of pumping power: the reactor stays full, water flows out of the vacuum breakers and guide tubes, and backflow occurs from the plenum or addition point backward through the heat exchangers and pumps to the bulk moderator space in each system where rotovalves are open after the pumps stop rotating. For a plenum line break: the reactor is drained and remains drained as long as the pumps operate, flow is down through the fuel and out of the outlet nozzles, flow is lost from the plenum through the broken nozzle, there is backflow through the septifoil system, and there is no backflow through the heat exchangers and pump because the pumps are operating.

\section{10 Loss of Pumping Power Accident}

The percent of flow to the fuel can be calculated if the internal and external hydraulic characteristics of the syotem are know. The external hydraulics are those for backflow (from addition point or pelnum to reactor) via the heat exchangers, piping, pumps, and septifoil system. The internal hydraulics are those for flow across the plenum and through the fuel. This accident differs srom the line break accident in that the reactor is full of water and the water losses from the plenum are smaller. 


\subsection{DISCUSSION (continued)}

This section gives the methods used to calculate the flow to the fuel for the power loss accident. The results in percent are given in Table 2.1.

\subsection{External Hrdraulics}

3.111 Main Piping and Heat Exchangers

For near normal flow rates, the equations in reference I were used to calculate the resistance of the heat exchangers and process piping. These equations are given in Table 3.11. The equation for the $C$ Area suction lines was used for all areas because they have the lowest resistance and more backflow would be calculated using the lower resistance. 
RTR

October 1, 1968

\section{Table 3.11}

\section{RESISTANCE OF PIPE AND HEAT EXCHANGERS AT NORMAL FLONS}

1. Resistance of line to plenum $=\Delta \mathrm{H}_{16}{ }^{1}$. in $\mathrm{ft}_{\text {. }}$

$$
\Delta \mathrm{H}_{I 6}^{I}=132.02\left(\frac{u}{p}\right)^{0.2} \frac{Q_{I 6}}{(20,000)^{1.8}}
$$

Where:

$$
\begin{aligned}
& (u / p)=\text { kinematic viscosity, } f t^{2} / \mathrm{sec} \\
& Q_{16}=\text { flow in the } 16 \text {-inch line, gpm }
\end{aligned}
$$

2. Resistance of suction line in C Area $=\Delta \mathrm{H}_{24}^{\prime}$ in ft

$$
\Delta H_{24}{ }^{1}=4.5\left(\frac{u}{p}\right)^{0.2} \frac{Q_{24}}{(20,000)^{1.8}}+5.78\left(\frac{Q_{24}}{20,000}\right)^{2}
$$

Where:

$$
\mathrm{Q}_{24}=\text { flow in the } 24 \text {-inch line, gpm }
$$

3. Resistance from purp through heat exchanger $=\Delta H_{\mathrm{HX}}$ in it.

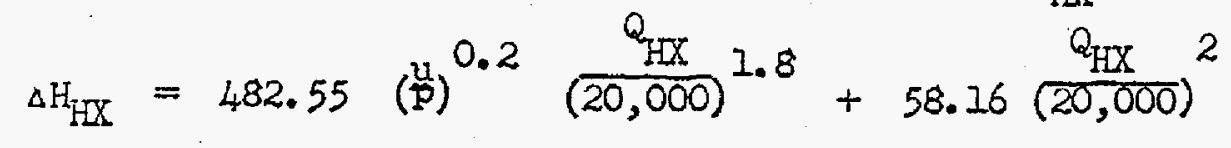

Where:

$$
Q_{\text {WX }}=\text { flow through the heat exchanger, gpm }
$$


$\mathrm{RTR}$

October I, 1968

\subsection{DISCUSSION (continued)}

\subsection{External Hydraulios (continued)}

3. Il1 Main Piping and Heat Exchangers (continued)

For the lower flow rates that occur when flow is supplied by the ECWA system, these equations were converted to equations in terms of iriction factor because the equations in Table 3.11 assume the friction factor is a constant divided by Reynold's number to the 0.2 power and they are only valid at near normal flows. The modified equations are given in Table 3.12 and typical resistances are shown in Table 3.13 .

The resistance of the pipes and heat exchangers to flow from the plenum through the pumps to the reactor (backflow) was considered to be the same as for flow in the normal direction. 
RTR

October 1, 1968

\section{Table 3.12}

\section{PIPE AND HEAT EXCHANGER RESISTANCES AT LON FLOWS}

1. . Resistance of Iine to plenum $=\Delta \mathrm{H}_{16}$ in ft.

$$
\Delta H_{16}=1050 f\left(\frac{Q_{16}}{20,000}\right)^{2}
$$

Where:

$$
\begin{aligned}
& Q_{16}=\text { flow in } 16 \text {-inch line } * \mathrm{gpm} \\
& f=\text { Hody friction factor, reference } 2=.0132010,0006 \mathrm{PM}\}^{j t}
\end{aligned}
$$

2. Resistance of suction line to pump $=\Delta \mathrm{H}_{24}$ in ft.

$$
\Delta \mathrm{H}_{24}=(218 f+4.47)\left(\frac{Q_{24}}{20,000}\right)^{2}
$$

Where:

$$
\begin{aligned}
Q_{24} & =\text { flow in } 24-\text { inch line, gpm } \\
f & =\text { Moody friction factor, reference } 2=.010001,400 \text {. }
\end{aligned}
$$

3. Resistance from pump through heat exchanger $=\Delta \mathrm{H}_{\mathrm{LX}}$ in $\mathrm{f}^{\prime}$.

$$
\Delta H_{\mathrm{HX}}=\left(2100 f_{\mathrm{m}}+1050 f_{16}+35.4\right) \frac{\left(Q_{H X}\right)^{2}}{20,000}
$$

Where:

$$
\begin{aligned}
Q_{\mathrm{HX}}= & f_{\text {Low through heat exchanger, gph }} \\
f_{\mathrm{T}}= & \text { Moody friction factor in heat exchanger tubes, } \\
& \text { reference } 2 \\
f_{16}= & \text { Moody friction factor in } 16 \text {-inch pipe between } \\
& \text { puriog and heat excharger }
\end{aligned}
$$


RTR

October I, 1968

Table 3.13

TYPICAL HEAD LOSSES

- Flow rate, gpm

- joss through fuel, $\Delta H_{f}$

- Loss across plenum, $\Delta H_{P I}$

- Ioss in 16 inch line to plenum, $\Delta \mathrm{H}_{16}$

- Ioss in heat exchanger

- Ioss in 24-inch line reactor to pump, $\Delta \mathrm{H}_{16}$

- Loss across pump, $\Delta H_{p}$

- Loss in S-foil system, $\Delta H_{S F}$
Featolioss, it

$500 \quad 1000 \quad \underline{5000} \quad 10,000$

$\begin{array}{llll}0.013 & 0.029 & 0.212 & 0.842\end{array}$

$0.004 \quad 0.012 \cdot 0.036 \cdot 0.300$

$\begin{array}{llll}0.010 & 0.040 & 0.920 & 3.470\end{array}$

$0.249 \quad 0.547$

$0.006 \quad 0.021$

1.600

3.320

$1.55 \mathrm{ft}$ at $100 \mathrm{gmm} / \mathrm{stat}$ 
RTR

October 1, 1968

\subsection{DISCUSSION (continued)}

\subsection{External Hydraulics (continued)}

\subsection{Septifoil system}

The septifoil flow equation below was developed from curves in reference 1 .

$$
\Delta H_{S F}=u_{4}, 400 f\left(\frac{Q_{S F}}{1333}\right)^{2}
$$

Where:

$$
\begin{aligned}
\Delta H_{S F}= & \text { The head loss from the heat exchanger } \\
& \text { to the bulk space, feet } \\
f= & \text { Moody friction factor, reference } 2 \\
Q_{S F}= & \text { Flow per system through septifoils, gar: }
\end{aligned}
$$


RTR

October 1, 2968

\subsection{DISCUSSION (continued)}

\subsection{External Hydraulics (continued)}

\subsection{Pumps}

When the pumps are operating, they add energy to the system. The punp head curve shown on Figure 3.11 is valid for these cases.

When the pumps are not operating and there is reverse Ilow through them, they have the resistance shown on Figure 3.12 . This curve was constmuted using the generalized graph in reference 3, and correcting it for a measured point from reference 4. The generalized curve gave a resistance 21.8 ft. (or about 20\%) less than the measured value of $110 \mathrm{ft}$. at $14,000 \mathrm{gpm}$. 


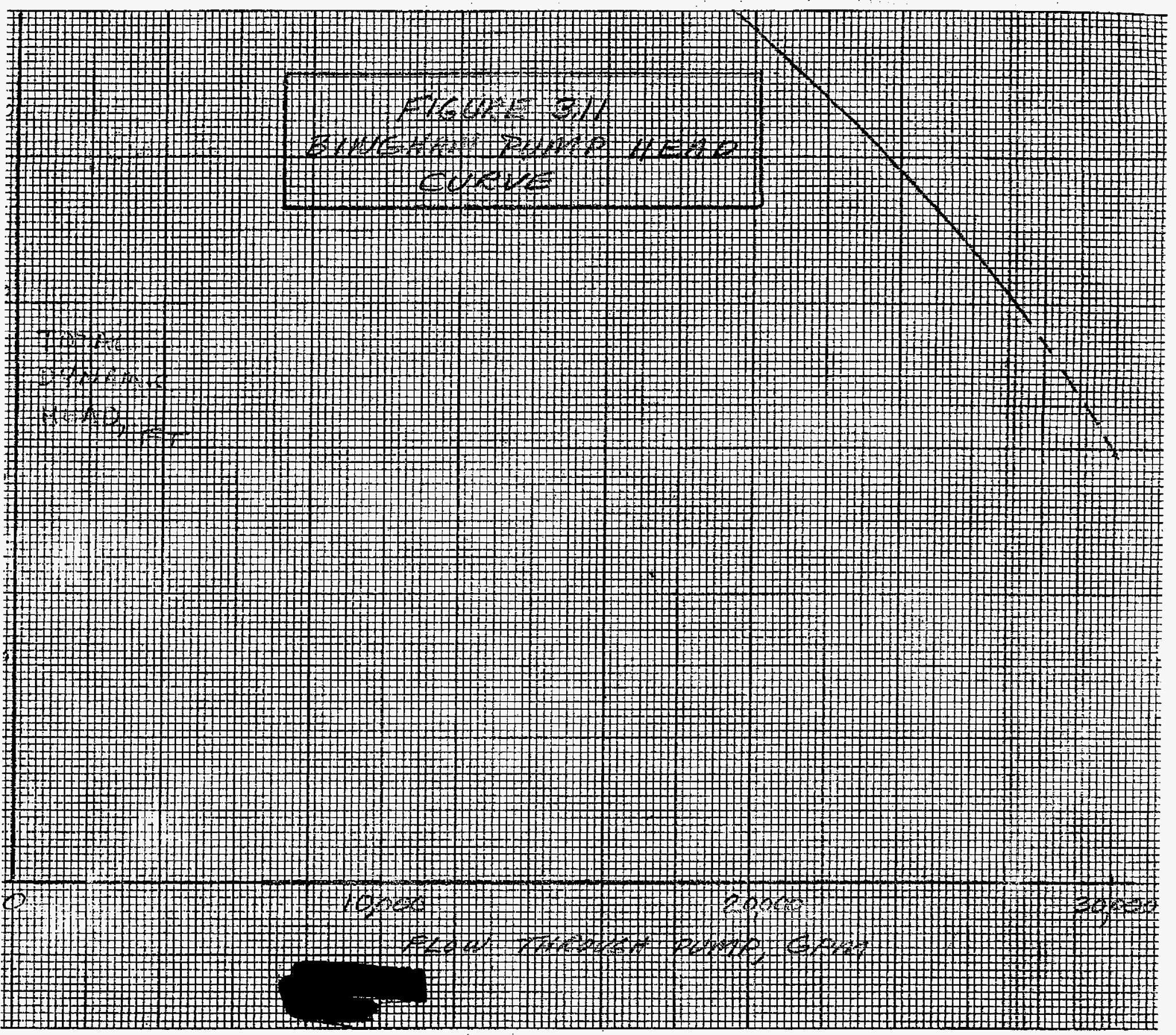


3

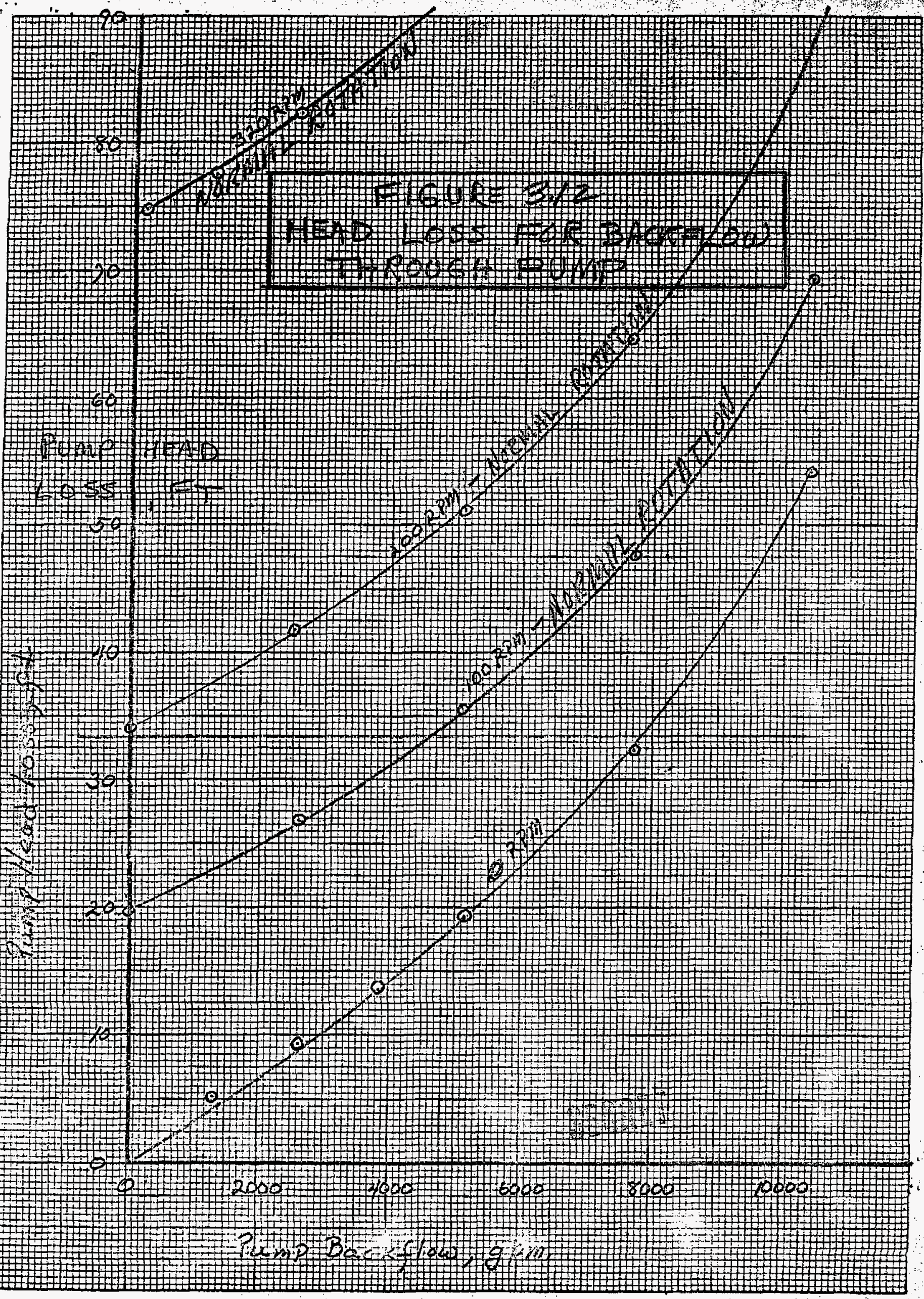


RTR

Ootober I, 1968

\section{$3 . \infty$ DISCUSSION (continued)}

\subsection{Plenum Resistance}

3.121 Plenum Gradient for Mark 14-ED Charge

The equation from reference 1 for full reactor charges was used for normal flow rates. At low Llows, the equation below, that is in terms of friction factor, was used. It is assumed the flow distribution at low flows is the same as at normal flow with the plenum full.

$\Delta H_{P L}=1014 f\left(\frac{Q_{f}}{120,000}\right)$

Where:

$$
\begin{aligned}
\Delta H_{P L} & =\text { the plenum gradient, } f t . \\
f & =\text { Moody friction factor, reference } 2 A \\
\rho & =\text { flow to fuel and sparjets, gpm. }
\end{aligned}
$$

Figure. 3.13 shows plenum gradient at low flows. 

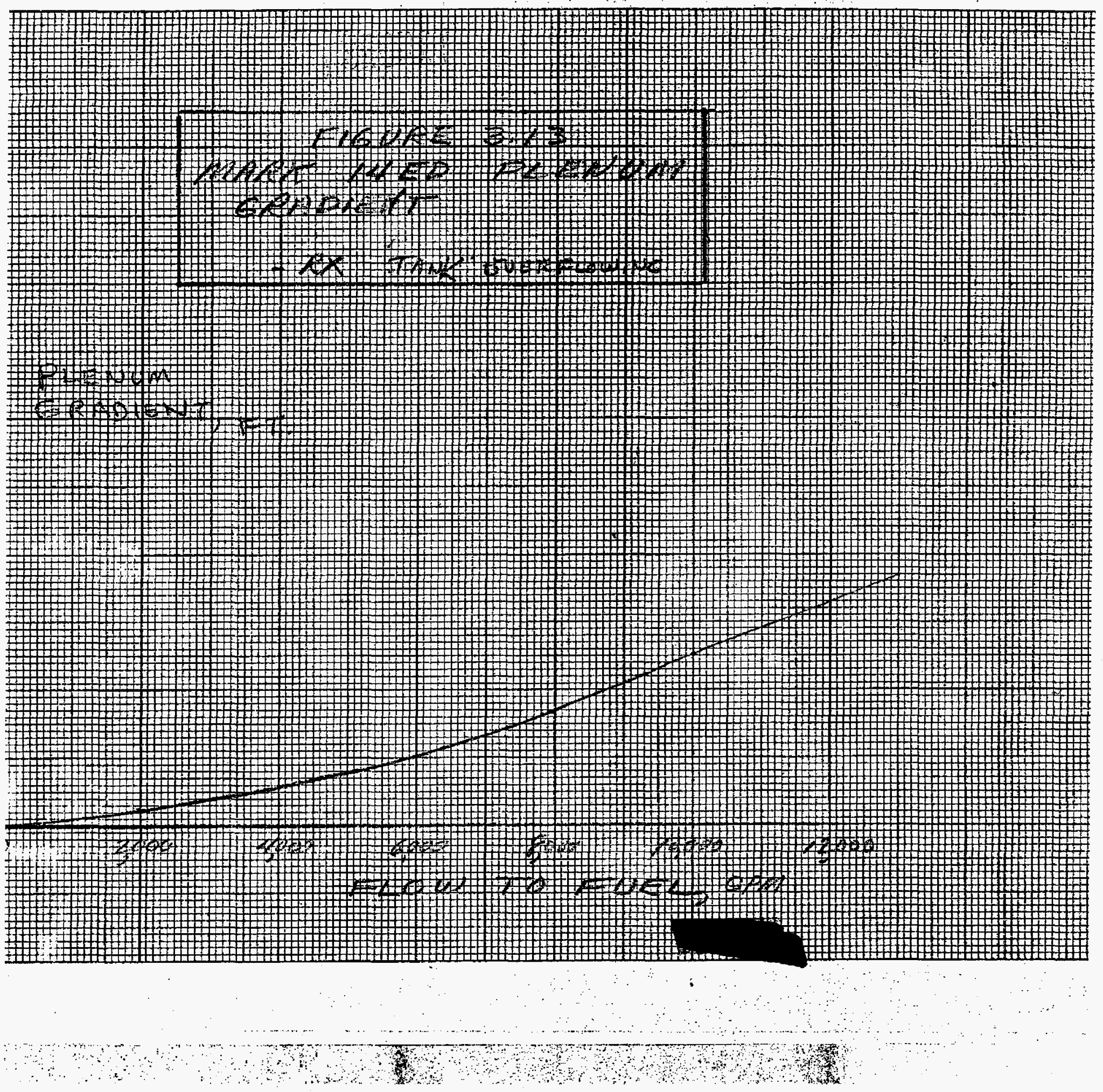
Rough Draft

\subsection{DISCUSSION (continued)}

\subsection{Plenum Resiatance (continued)}

3.122 Plenum Gradient for High Flux Charge

The equation for pressure arop across a bank of staggered tubes (reference 5) was used to determine the pressure drop across each row of sleeves in the reactor plenum. ${ }^{*}$ The total plenum GRADIEST the sum of the inditidual pressure drops for each row of tubes.

Equation:

$\Delta \mathrm{H}_{\mathrm{PL}}=\frac{15}{1} 0.005807\left(\frac{1.8}{2}\right.$

Where:

$$
\begin{aligned}
\Delta H_{Y L} & =\text { the plenum gradient, feet } \\
V & =\text { the velocity between sleeves for row } n \\
& \text { in feet per second }
\end{aligned}
$$

Figure 3.14 shows the plenum gradient for the high flux charge at low flows.

* This equation coupled with the slot flow equation in section 3.23 gare a fair agreement with test data for $\mathrm{t}$ Area with a low level (Figure 3.26). 
Rough Draft.

RIR

Ootober 1,1968

\subsection{DISGUSSION (continued)}

\subsection{Pruel Charge}

\subsection{Resistance of Mark $U_{4}$ - 1 Charge}

For normal full flow, the test station equations are used along with plenum gradient to get the total charge resistande. To simplify the calculations at low flow rates, it was assumed that the flow distribution, row by row, is the same as long as the reactor is full. With this assumption, the resistance of the charge varies as the resistance of the fuel assemblies and targets in the center of the reactor. For the Hark 14-ED charge, the charge resistance was assumed to vary: as the resistance of a cell consisting of one fuel tube and one target. The fueI and target equation used are:

$$
\begin{aligned}
& \left.\left.\Delta \mathrm{H}_{\mathrm{M} 4}=(113 f) 8.4\right) \frac{\left(\mathrm{MMH}_{4}\right.}{100}\right)^{2} \\
& \Delta \mathrm{H}_{\mathrm{M} 3}=(6925+8.35) \frac{\left(\mathrm{Q}_{\mathrm{M} 30}\right)^{2}}{100}
\end{aligned}
$$

Where:

$$
\begin{aligned}
\Delta \mathrm{H}_{\mathrm{MC}} \text { and } \triangle \mathrm{H}_{\mathrm{MBO}} & =\text { assembly head losses, feet } \\
\mathrm{Q}_{\mathrm{M} \mathrm{M}_{4}} \text { and } \mathrm{Q}_{\mathrm{M} 30} & =\text { assembly flows, gpm } \\
f & =\text { Moody friction factor, reference } 2
\end{aligned}
$$

It should be noted that the ratio of fuel to target flow in the cell changes at low flows because of friction factor changes. In some cases, one is in laminar flow when the other is not.

Figure 3.15 shows charge flow versus head at the center of the plenum for low flows. 

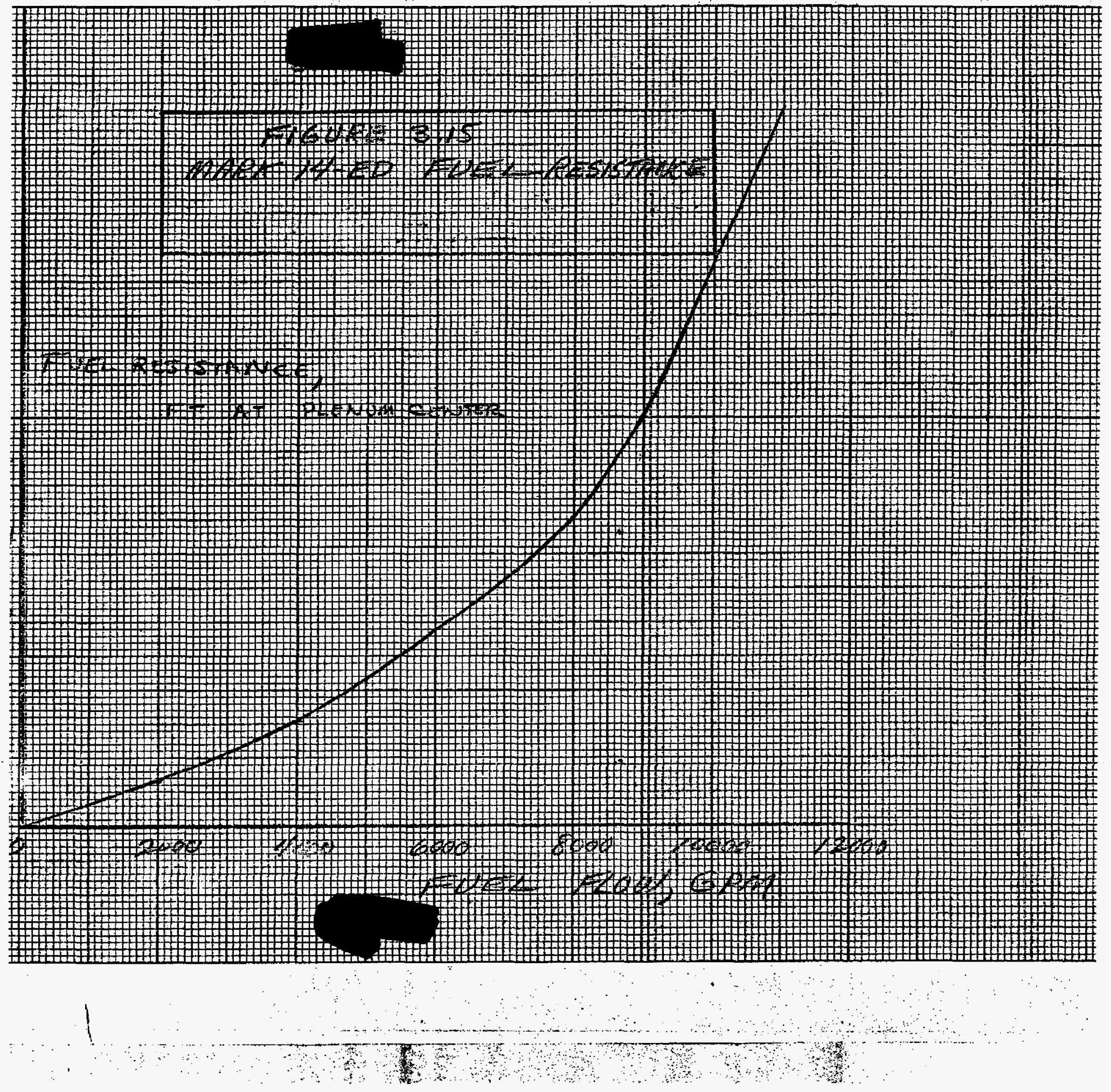

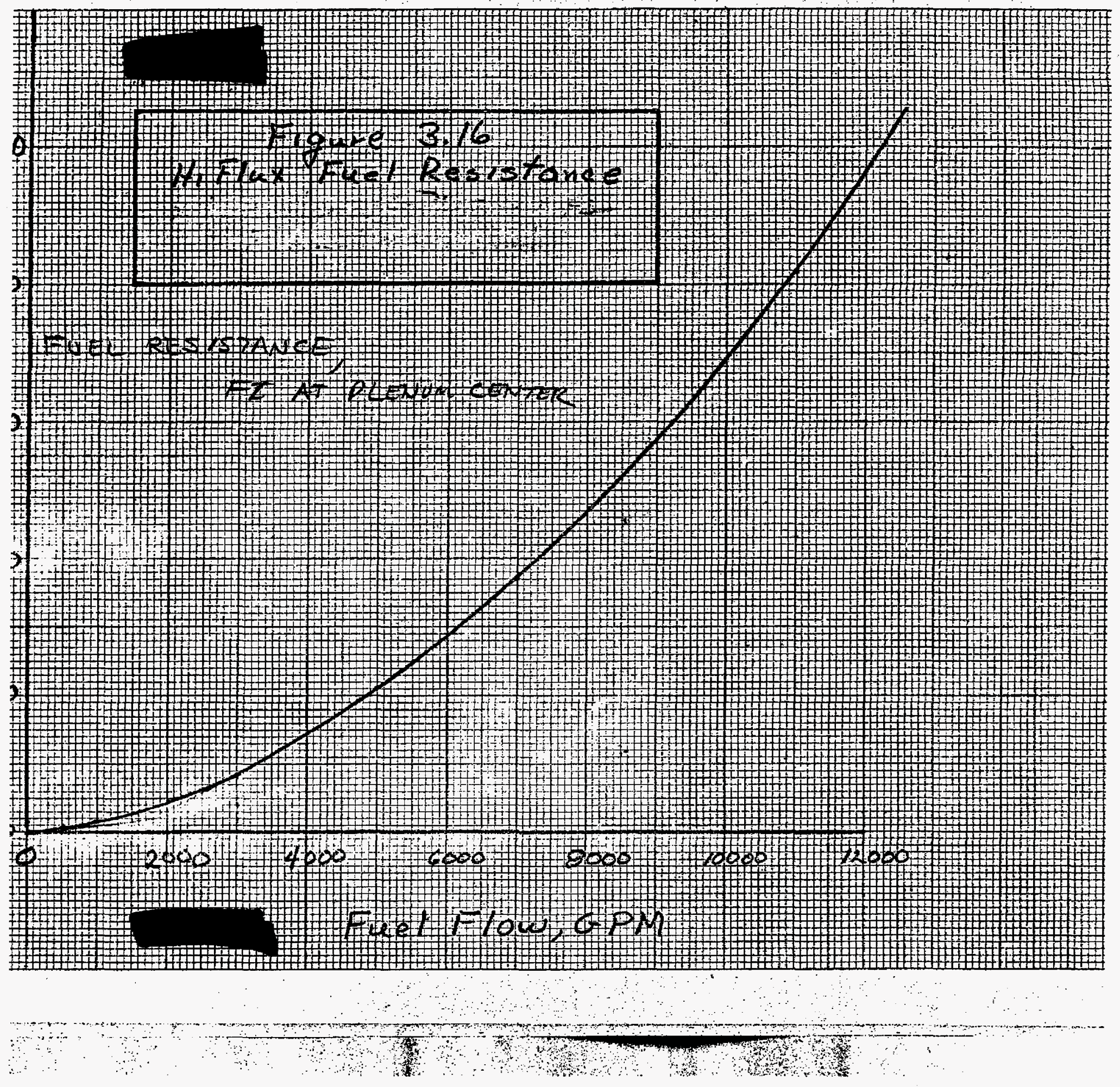
Rough Draft

$-20$

$\mathrm{RTR}$

October 1, 1968

3.00 DISCUSSION (continued)

3.13 Fuel Charge

3.132 Resistance of High Flux Charge

Fuel resistance for the high flux was determined using the hydraulic data predicted in reference 6. The equation used was:

$$
\Delta H_{\mathrm{HS} \emptyset}=5.49 \mathrm{f}(\mathrm{v})^{2}
$$

Where:

$$
\begin{aligned}
\Delta H_{\text {HS }} \varnothing & =\text { assembly head losses, feet } \\
\nabla & =\text { average assembly velocity, feet per second } \\
f & =\text { Moody friction factor }
\end{aligned}
$$

Figure 3.16 shows charge flow versus head at the center of the plenum for low flows. 


\subsection{DISCUSSION (continued)}

\subsection{Calculation of Percent Flow to Fuel}

Finding the percent flow to the fuel consists of finding the amounts of backflow and fuel flow that require the same plenum head and add up to the $11,000 \mathrm{ggm}$ available ECW flow. The results of the calculations are shown on Table 2.I.

\subsection{Backflow in Addition Systems (2 and 5)}

The equations related to backflow in systems 2 and 5 are below. There were used with those in section 3.142 for trial and error determination of backflow.

$\Delta H_{f}+\Delta H_{P L}+\Delta H_{16 A}=\Delta H_{H X}+\Delta H_{P}+\Delta H_{24}$ and, $\Delta \mathrm{H}_{f}+\Delta \mathrm{H}_{P L}+\Delta \mathrm{H}_{I 6 \mathrm{~A}}=\Delta \mathrm{H}_{\mathrm{SF}}$

$$
\begin{aligned}
& Q_{B}=5500-Q_{I 6 A} \text { and, } \\
& Q_{F}=21,000-2 Q_{B}-2 Q_{S F A}-4 Q_{B O}-4 Q_{S F O}
\end{aligned}
$$

\section{Where:}

$$
\begin{aligned}
& \Delta \mathrm{H}_{16 \mathrm{~A}}=\text { resistance of } 16 \text {-inch line in systems } 2 \text { and } 5 \\
& \text { to normal flow (5500 gpm - QB ) j feet } \\
& Q_{I 6 A}=\text { flow to plenum in system } 2 \text { or } 5\left(5500-Q_{B}\right){ }_{j} \text { gand } \\
& Q_{B} \quad=\text { backflow through heat exchangers and pumps } \\
& \text { in systems } 2 \text { and } 5 ; \text { grmox } \\
& \mathrm{Q}_{\mathrm{BO}}=\text { backflow in systems other than } 2 \text { and } 5,-5 \mathrm{gpm} \% \\
& Q_{\text {SFA }}=\text { septifoil flow in } / 2 \text { and } 5 \text { is gpol } \\
& \text { QSFO = septifoil flow in other four systems } \sim \text { grmpl }
\end{aligned}
$$


Rough Draft

$-22-$
TR

October 1,1968

3.00 DISGUSSION (continued)

3. I4 Calculation of Percent Flow to Fuel (continued)

3.142 Backflow In Systems 1, 3, 4 and 6

These equations relate to backflow in systems $1,3,4$, and 6 and are used with equations in section 3.142 for trail and error solution to get backflow.

$\longrightarrow$

$$
\begin{gathered}
\Delta \mathrm{H}_{\mathrm{f}}+\Delta \mathrm{H}_{\mathrm{PL}}=\Delta \mathrm{H}_{16}+\Delta \mathrm{H}_{\mathrm{FX}}+{ }_{\Lambda}+\Delta \mathrm{H}_{24} \\
\Delta \mathrm{H}_{\mathrm{f}}+\Delta \mathrm{H}_{\mathrm{PI}}+\Delta \mathrm{H}_{16}=\Delta \mathrm{H}_{\mathrm{SF}} \\
\mathrm{Q}_{\mathrm{f}}=11,000-2 \mathrm{Q}_{\mathrm{B}}-2 \mathrm{Q}_{\mathrm{SFA}}-4 \mathrm{Q}_{\mathrm{BO}}-4 \mathrm{Q}_{\mathrm{SFO}}
\end{gathered}
$$


3.00 DISCUSSION (continued)

\subsection{Plenum Iine Break Accident}

This acoident differs from the pump power loss accident because the reactor drains rapidly and the losses from the plenum are larger. The drained reactor changes the hydraulics in the fuel and plenum at low flow rates and makes the flow to the fuel limited by the plenum slot resistance. Because the pumps would be muning following a leak, the only backflow would be the flow to the septifoils. The only other $108 \mathrm{~s}$ from the plenum would be that which leaks out of the broken line.

This section gives the methods used to determine the leak rate, the backflow rate, and the flow rate to the fuel for the plenum line break accident.

\subsection{External Hydraulics}

\subsection{Main Plping and Heat Exchangerg}

The methods and equations in section 3.171 apply to all calculations of extermal system resistance for the main piping and heat exchangers.

\section{INFORMATION ONLY}


RTR

an 2,20

October. 2,1968

3.00 DISCUSSION (continued)

3.20 Plenum Iine Break Accident (continued)

\subsection{Septifoils}

The flow to the septifoils no longer follows the equation in 3.172 because the reactor is empty and at low flows most of the water to the septifoils is discharged from the lowest row of holes. The equation used for septifoil flow is given below.

$\Delta H_{S F}=1.51 \times 10^{-4}\left(Q_{\text {sys }}\right)^{2}+0.736 \times 10^{-4}\left(Q_{1}\right)^{2}$

Where:

$\Delta \mathrm{H}_{\mathrm{SF}}=$ height of liquid in heat exchanger discharge and septifoils $x$ piping minus the liquid level in the septifoi19 feetx

$Q_{\text {sys }}=$ total flow to the septifoils from one pump system, gam,

$Q_{1}=$ flow through bottom row of holes in septifoils, gpm.

When the valye for the second term of the equation above is less than 1.0 feet, $Q_{1}$ equals $Q_{\text {sys; }}$ when the value becomes greater than 1.0 feet, then:

$$
Q_{\text {sys }}=Q_{1}+Q_{2}+Q_{3}+-m Q_{3 \pi}
$$

Where:

$Q_{2}=$ flow through second row of holes in septifoil, gpm.

of = flow through nth row of holes in septifoilX

Figure 3.20 shows the septifoll system flow versus water level in the extermal D,O syratem piping. 


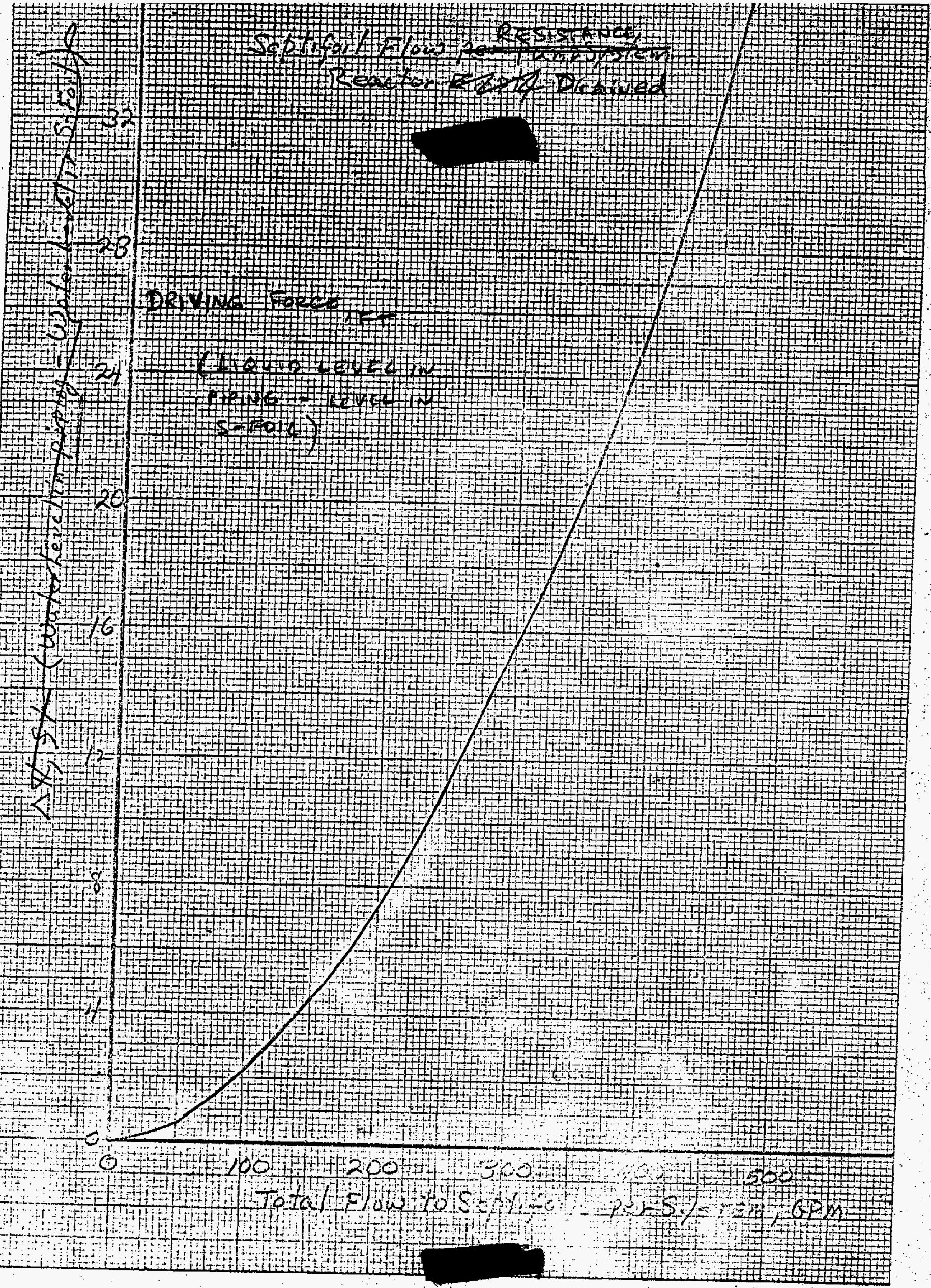


RTR

October 1, 1968

3.00 DISCUSSION (continued)

\subsection{Plenum Line Break Accident (continued)}

\subsection{Leak Rate and Resistance}

3.221 Pumps Running - Water in Reactor

For a sudden-double end break: plenum pressure would decrease, the pumps for the unbroken systems would increase their flow rate and a new equilibrium operating pressure that would provide reciuced flow through the fuel and leakage from the plenum would rapidly be established. At the same time, the flow through the pump on the broken system would increase until the resistance of the lines, heat exchangers, and nozzle (the broken end of the line) match a point on the pump head curve. The total leakage rate would be the flow through the pump on the broken system plus the leak from the plenum. It is assumed that equilibrium leakage rate would be attained almost immediately to simplify calculations. This section gives the method used to calculate the leak rate. Table 2.1 gives the calculated leak rates for. Mark $14-\mathrm{ED}$ and high flux. 
RTR

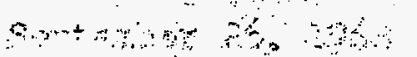

October 1,1968

\subsection{DISCUSSION (continued)}

\subsection{Plenum Line Break Accident (continued)}

\subsection{Ieak Rate and Resistance (continued)}

\subsection{1] Plenum Leak}

The equilibrium point is where the external system resistance plus the head at the edge of the plenum minus the decrease in reactor level equals a point on the pump head curre (Figure 3.17).

Because the plenum pressure is high, fuel resistance plus plenum gradient must be used to get the pressure at the edge of the plenum. The equations used for fuel resistance and plenum gradient are given below.

Mark $14-E D$

$$
\begin{aligned}
& \left.\left.\Delta \mathrm{H}_{f}\right]_{4}=137 \frac{Q_{\mathrm{F}} \mathrm{H}_{4}}{150,000}\right)^{2} \\
& \Delta H_{\text {PL } L_{4}}=35.3 \cdot\left(\frac{Q_{F} L_{4}}{150,000}\right)^{1.8}
\end{aligned}
$$

High Flux

$$
\begin{aligned}
\Delta H_{\text {fHI }}= & 244\left(\frac{\left.Q_{F H I}\right)^{2}}{103,000}\right. \\
& \text { and } \\
\Delta H_{\text {PLHI }}= & 58.7\left(\frac{Q_{F H I}}{103,000}\right)^{1.8}
\end{aligned}
$$




\subsection{Plenum Line Break Accident (continued)}

\subsection{Leak Rate and Resistance (continued)}

3.2211 Plenum Leak (continued)

Where:

$$
\begin{aligned}
& \Delta H_{f}=\text { fuel head loss, feetx } \\
& \Delta H_{P L}=\text { plenum gradient, feet } \\
& Q_{F}=\text { flow to fuel, gpm. } \\
& 14 \text { refers to Mark } 14 \text {-ED chargex } \\
& H I \text { refers to high flux chargex }
\end{aligned}
$$

The leak from the plenum via a nozzle should have a pressure drop of about one velocity. head and this should be the pressure at the edge of the plenum.

$$
\begin{aligned}
\Delta \mathrm{H}_{\mathrm{L}}= & 0.01554 \frac{\left(\mathrm{Q}_{\mathrm{I}}\right)^{2}}{64 \mathrm{~L}} \\
& \text { and } \\
\Delta \mathrm{H}_{\mathrm{L}}= & \Delta \mathrm{H}_{\mathrm{I}}+\Delta \mathrm{H}_{\mathrm{PL}}
\end{aligned}
$$

Where:

$$
\begin{aligned}
& \Delta H_{L}=\text { head loss for leak, feet } \\
& Q_{L}=\text { leak rate, gpm }
\end{aligned}
$$




\subsection{Plenum Iine Break Accident (continued)}

\subsection{Leak Rate and Resistance (continued)}

\subsection{Plenum Leak (continued)}

The flow to the plenum at any $\Delta \mathrm{H}_{L}$ is:

$$
Q_{P L}=Q_{L}+Q_{f}
$$

Where:

$$
\mathrm{Q}_{\mathrm{PL}}=\text { flow to plenum, gparl: }
$$

The extermal system resistances were determined using the equations in 3.171 and assuming a septifoil flow Ioss of $1200 \mathrm{gpm}$ per system as a constant for simplification.

To get the leakage rate from the plenum, a head required curve for flow to the plenum (in terms of flow per pump) was constructed using the external system resistances and $\Delta \mathrm{H}_{\mathrm{L}}$ (equal to $\Delta \mathrm{H}_{\mathrm{f}}+\Delta \mathrm{H}_{\mathrm{PI}}$ ). This curve (Figure 3.21) was plotted on a pump head curve and the intersection was used as the operating point assuming there would be no cavitation. Leakage rates for lower levels were determined by subtracting the level decrease from the pump head curve and getting a new intersection. With this operating point, the $\Delta H_{L}$ was used to calculated the leakage rate from the plenum. 
RTR

October 1, 1968

\subsection{DISOUSSION (continued)}

3.20 Plenum Iine Break Accident (continued)

3.22 Leak Rate and Resistance (continued)

3.2212 Pump Side Leak

To get the leakage rate from the pump side of the broken line, the section 3.111 equations for heat exchanger and suction lines were used and the loss at the. end of the pipe was assumed to be one velocity head. These total resistances were plotted as a head required curve (Figure 3.21) on the pump head curve and treated in the same way as the head required curves for plenum flow to get operating points at various levels. All operating points were above $32,000 \mathrm{gpm}$. Because the pumps will cavitate somewhere slightly above $30,000 \mathrm{gpm}$ with $30^{\circ} \mathrm{C}$ water flowing a rate of $31,000 \mathrm{gpm}$ was assumed for this loss. 


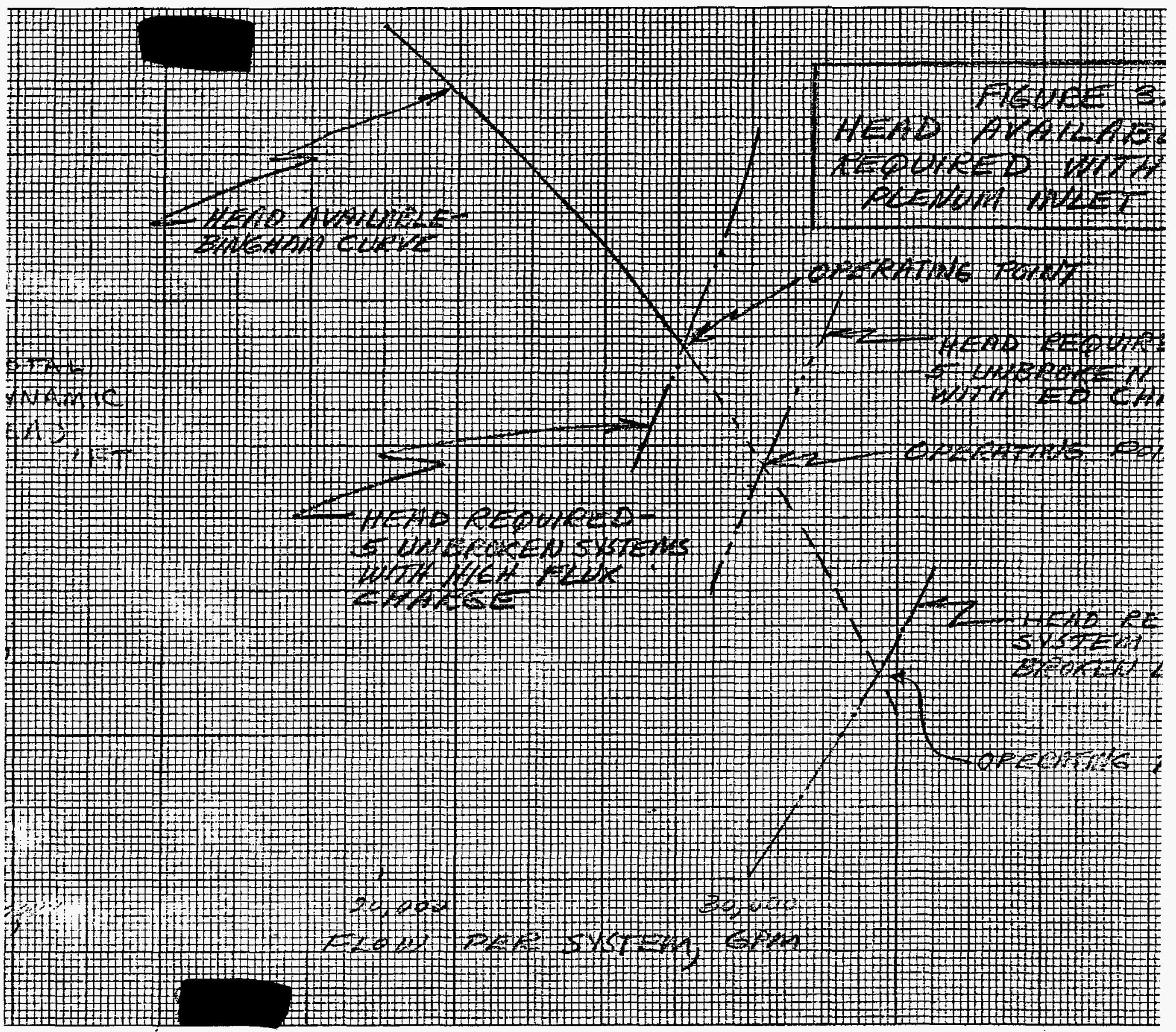


RTR

\subsection{DISCUSSION (continued)}

3.20 Plenum Line Break Accident (continued)

3.22 Lesk Rate and Resistance (continued)

3.222 Pumps Running - No Water in Reactor

After the reactor is pumped dry and the pump suction legs are empty, the pumps hold the leg of water to : the plenum (and prevent backflow), but there is no flow to the plenum or the leak. When emergency cooling water is added, a part of it is lost through the leak.

The closest hydraulic model of the leak when the plenum is not full is an overflow line. The equation for such a line was used to calculate leak rates and is given below.

$$
Q=1495.5 \quad(\mathrm{I}) \mathrm{H}^{3 / 2}
$$

Where:

$\mathrm{F}=\mathrm{h}+0.25$

$h$ is the height of liquid in plenum in feet Qe) is leak rate in gam

$I$ is plpe cord length of liquid level, $H$, feet.

When the plenum is full at the edge, it is assumed that there is one velocity head loss through the leak and rates' are calculated for velocity head in the inlet line. 
RTR

October 1, 1968

\subsection{DISCUSSION (continued)}

\subsection{Plenum Line Break Accident. (continued)}

\subsection{Plenum and Fuel Resistance}

After the reactor is drained and emergency cooling water is added, the flow to the fuel will be limited by the resistance of the plenum slots and the flow distribution is much different than for a full reactor. To determine if flow is adequate, the flow to the assemblies in the center of the reactor must be determined as must the flow that goes to the plenum. This section gives the methods used to calculate the plenum resistance assuming flow is distributed like it would be adding water equally to two systems on opposite sides of the plenum. The leak case is somewhat different from this because operation of the bottom addition system will result in more water being added to one side and leakage through a broken line will change the plenum distribution some.

The equation developed for pressure drop across the plenum (section 3.122) was used to calculate the plenum gradient for a Mark 14-ED charge and a high flux charge. A step by step calculation starting in the reactor center was used to determine the flow to the fuel in each row of fuel assemblies versus plenum shot height. The velocity for each row was determine from the sum of the flows passing through the row and the height of water at. the row. The equation for flow to a fuel position is: 
ATR

3.00 DISCUSSION (continued)

\subsection{Plenum Iine Break Accident (continued)}

3.23 Plenum and Fuel Resistance

$$
\begin{aligned}
& \left.\Delta \mathrm{H}_{\text {slots }}=0.5 \text { (Q } \mathrm{Q}_{\text {slots }}\right) \\
& \text { Where: }_{\Delta \mathrm{H}_{\text {slots }}}=\text { height of liquid in reactor at the row, inches } \\
& \mathrm{Q}_{\text {slots }}=\text { flow of liquid into sleeve, gpm }
\end{aligned}
$$

Figure 3.22 shows the plenum gradient for a Mark $Z_{4}$-ED

charge at low flows with the reactor empty and Figure 3.24

shows the plenum gradient for the high flux charge.

This method gives a central tube flow of 3.3 gpm for an ED charge at $13,400 \mathrm{gpm}$ total flow compared to a minimum of 3.6 gpm measured for a full charge in I Area (Figure 3.26 and reference 7).

Figure 3.23 shows the flow.to the center fuel tube versus the total flow to the fuel for a Mark 14-ED charge with the reactor empty and Figure 3.25 shows the flow to the center fuel tube versus the total flow to the fuel for a high flux charge. 
RTR

\section{$3 . \infty$ DISCUSSION (continued)}

3.20 Plenum Line Break Accident (continued)

\subsection{Plenum and Fuel Resistance}

Table 3.21 shows the plenum head and flow distribution with a large leak. It gives the results of the row by row calculated pressure drop across the reactor plenum with the reactor empty, and with a Mark 14-ED charge. The total fuel flow is about 8,000 gpm.

\section{Table 3.21}

\section{WATER IEVEL IN PLENUM AND FUEL FLOW BY ROWS}

0.75

0.7719

0.8172

0.8619

0.9441

1.0536

1.1923

1. 3682

1. 5759

1. 8378

2. 1561

2. 5510

3.0547

3. 7122

4.6146
2.0

2.05

2.23

2.45

2. 83

3.36

4.10

5. 15

6.45

8.30

10.7

14.0

19.2

25.8

36.3 


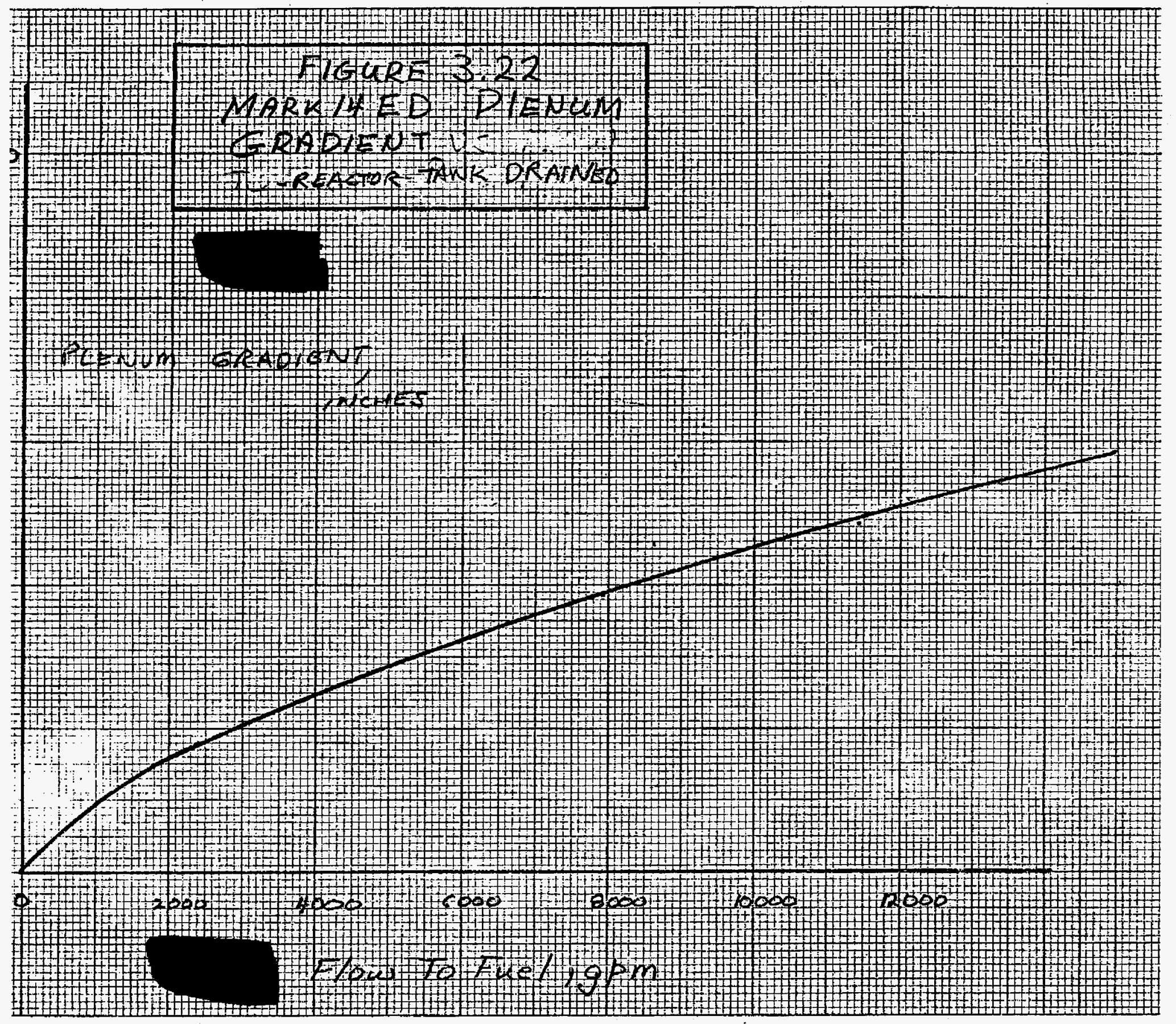




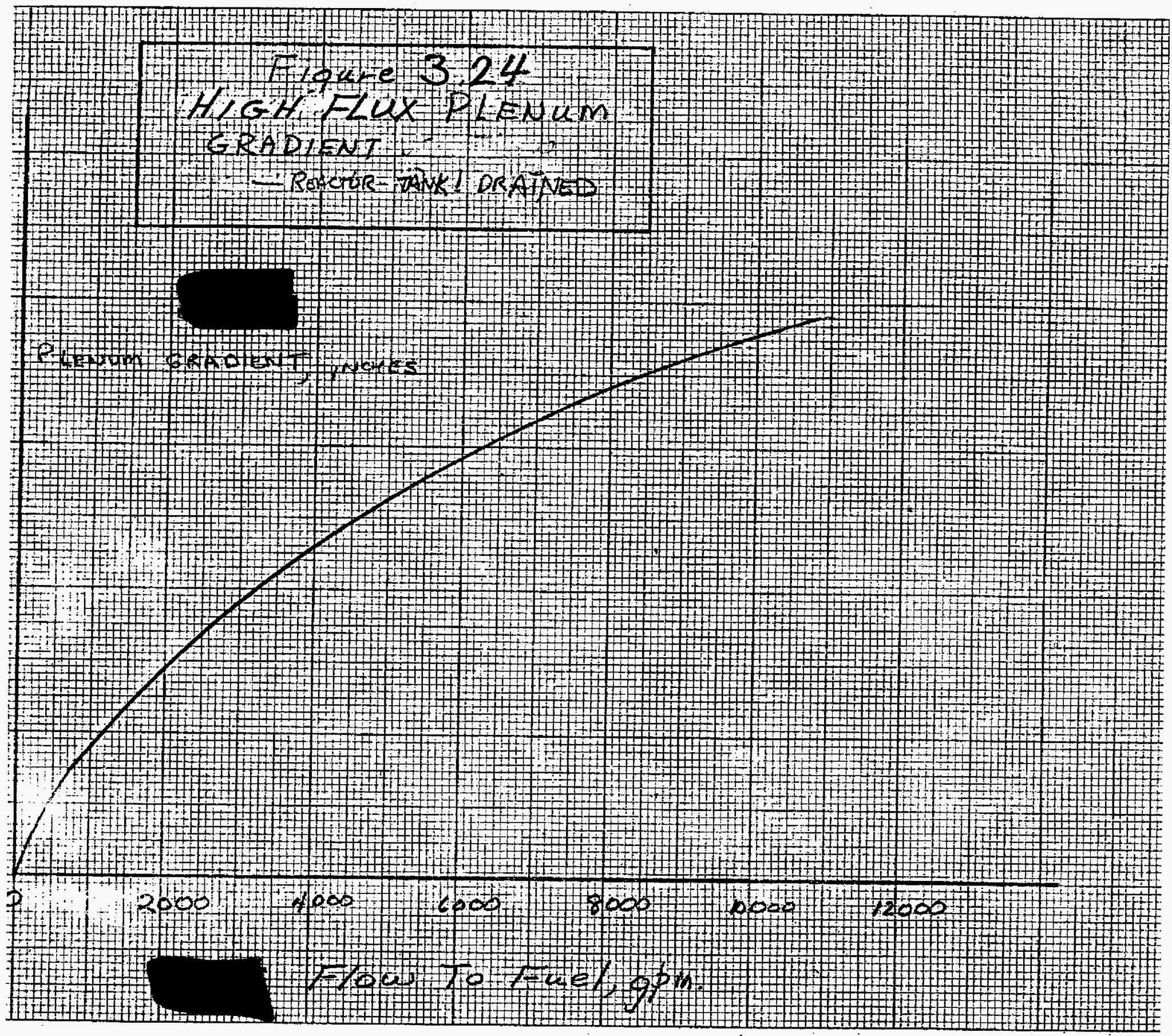


3.00 DISCUSSION (continued)

\subsection{Plenum Iine Break Accident (continued)}

3.24 Calculation of Flow to Fuel

The percent flow to the fuel can be found by finding the leak rate, septifoil backflow, and fuel flow that add up to 1I,000 gpm for the same plenum head. This is a trail and error solution of equations presented in sections 3.212, 3.222 , and 3.223 .

Knowing the actual flow to the fuel, the flow to the central tubes can be determined from Figure 3.23 or Figure 3.25. 


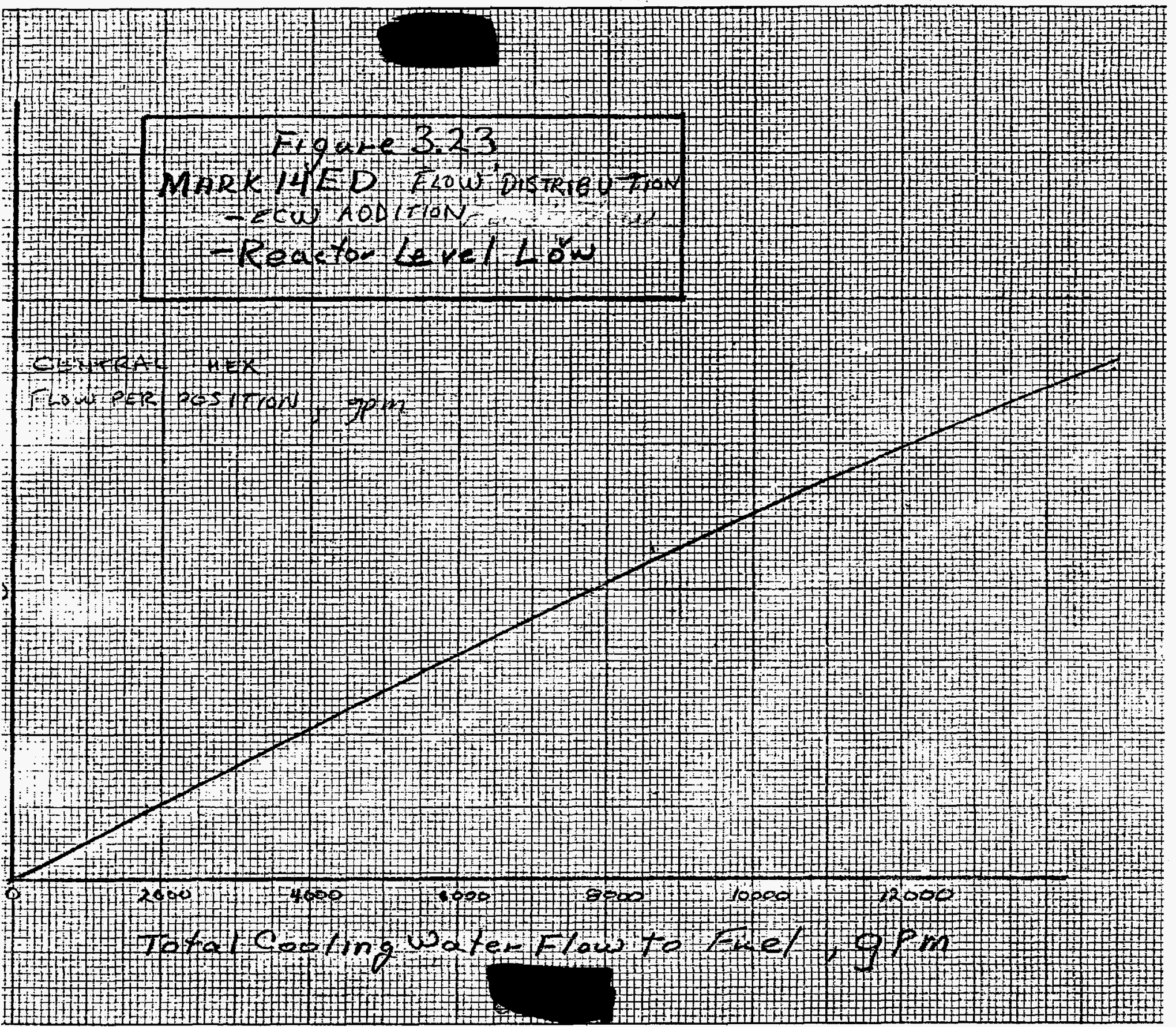




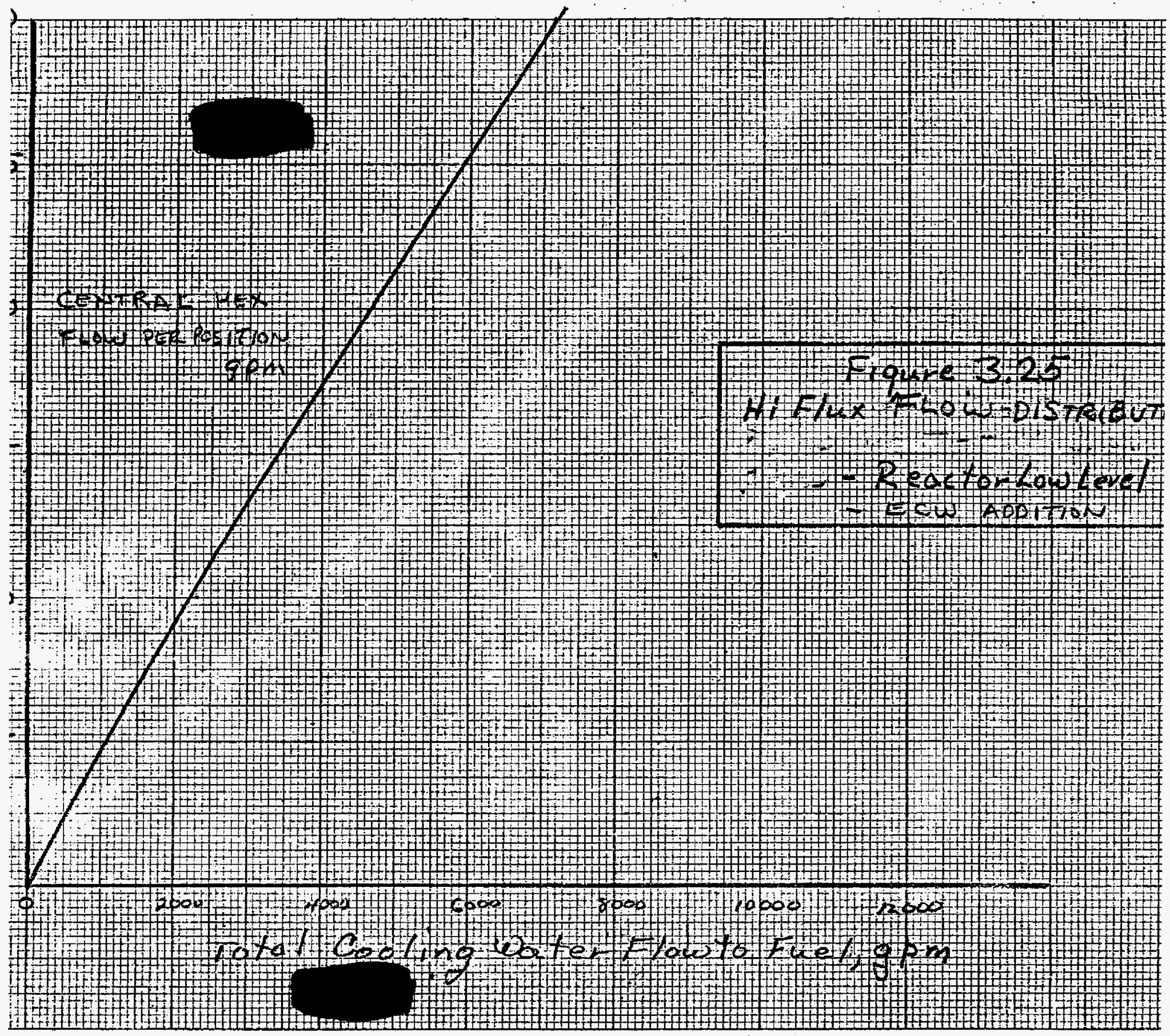


प

(1)

(

8

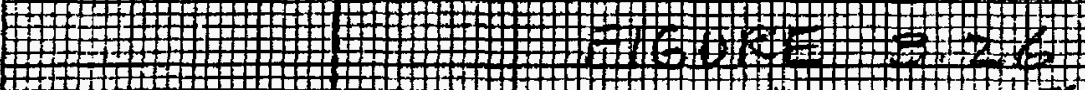

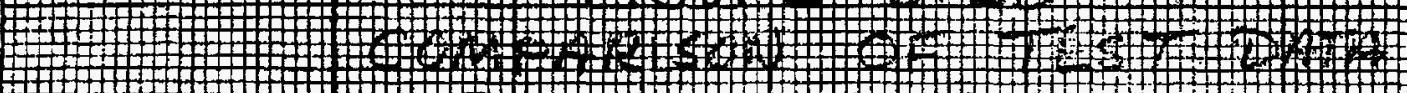

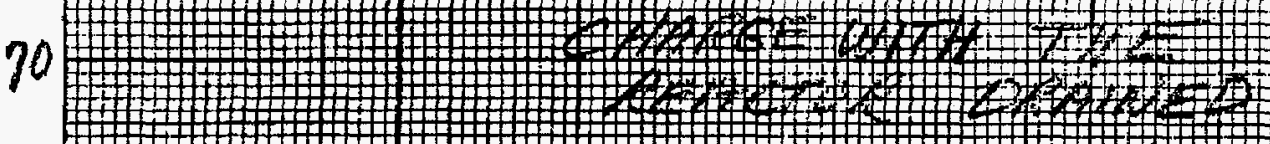

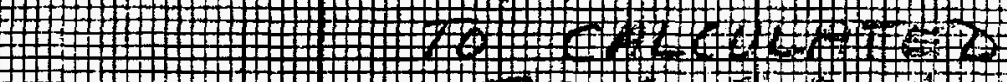

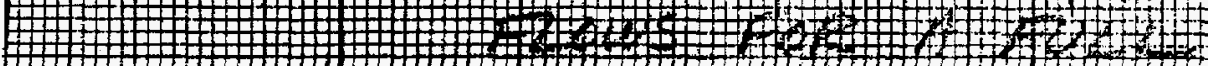

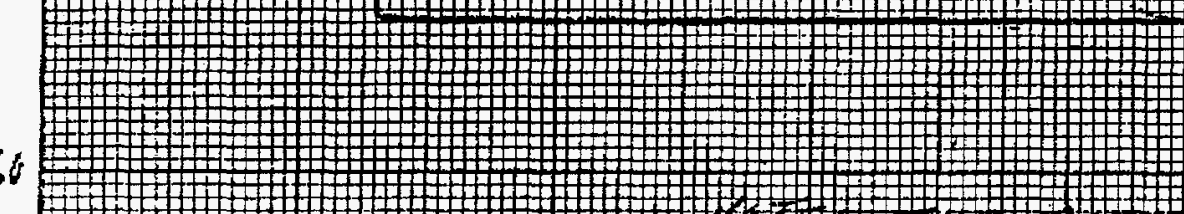

60

40

$5 0 \longdiv { + 1 + 1 4 }$

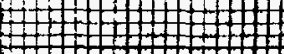

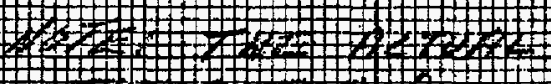

$+$

厓

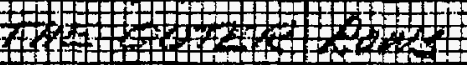

42

(2)

$+1+12$

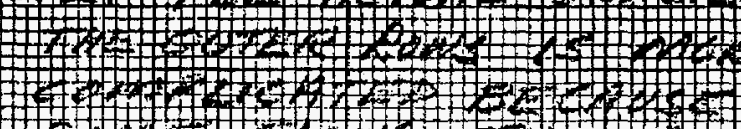

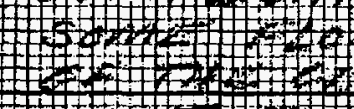

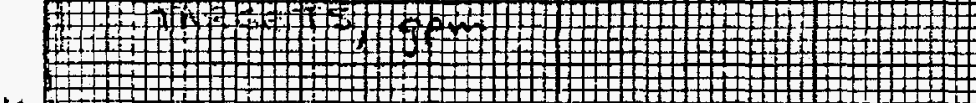

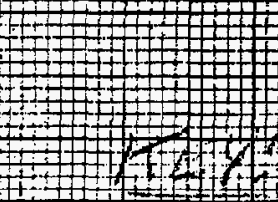

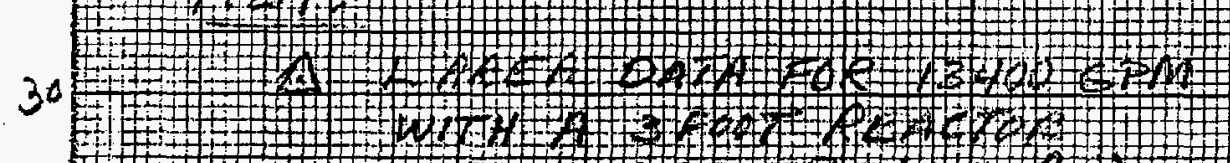
$\frac{12+2}{2+2}$

(1) 


\section{BEFERENCES}

1. Bland, C. A., RTR 912, "Process System Hydraulics," DPSP-66-1637, January 1967 (Secret).

2. Moody, I. F., Paper in November 1944 Transactions of the ASME, "Friction Factors for Pipe Flow,"

3. Stephanoff, A. J., book, "Centrifugal and Axial Flow Pumps," second edition, Figure 13.2, 1957.

4. Field, F. R., RTR 39, "Hydraulic Test Data - C-6," DPSP-57-662, ApriI 1957 (Secret).

5. Perry, J. H., Handbook, "Chemical Engineers' Handbook," third edition, 1950, pages 391 and $409-410$.

6. Wingo, H. E., Menorandum to Mirshak, S., "Proposed High Flux Californium Charge," DPST-68-382, May 1968 (Secret).

7. Reactor Technology Engineering Section of Monthly Report for November 1962, DPSP 62-I-11 (Secret).

CJT: cha 